\title{
A COMPARISON OF FINE-BORE SUPRAPUBIC AND AN INTERMITTENT URETHRAL CATHETERISATION REGIME AFTER SPINAL CORD INJURY*
}

\author{
By D. J. Grundy, F.R.C.S., ${ }^{1}$ G. J. Fellows, M.S., F.R.C.S., ${ }^{2}$ A. P. \\ GilletT, M.R.C.P., M.R.C.Path. ${ }^{3}$ I. NuSEIBEH, F.R.C.S. ${ }^{4}$ and J. R. \\ Silver, F.R.C.P. Ed \& Lond. ${ }^{4}$ \\ $1 \star \star R e g i s t r a r$ in Spinal Injuries, ${ }^{2}$ Consultant Urologist, ${ }^{3}$ Consultant Microbiologist, \\ ${ }^{4}$ Consultant in Spinal Injuries, National Spinal Injuries Centre, Stoke Mandeville \\ Hospital, Aylesbury, Bucks. HP2I $8 A L$
}

Summary. A prospective trial, comparing fine-bore suprapubic cathetisation and intermittent urethral catheterisation as methods of bladder drainage in the acute stage following spinal cord injury, was conducted. The results showed no important difference in either method of bladder management. Fine-bore suprapubic catheterisation is particularly suitable for young female patients, who find repeated urethral catheterisation distasteful; in other patients it is an acceptable alternative to intermittent urethral catheterisation, particularly where economic considerations are paramount.

Key words: Spinal cord injury; Fine-bore suprapubic catheterisation; Intermittent urethral catherisation.

\section{Introduction}

THERE IS no universally accepted method of bladder drainage in the acute stage following spinal cord injury. Four principal methods are employed: (a) intermittent urethral catheterisation (IUC), which has been the method of choice at the National Spinal Injuries Centre (NSIC) for many years (Guttmann, I947; Guttmann and Frankel, I966); (b) expression by suprapubic pressure (Golding, I968); (c) indwelling urethral catheterisation, and (d) fine-bore suprapubic catheterisation (SPC) (Smith, Cook \& Robertson, I969).

Expression by suprapubic pressure, although appearing to be satisfactory in Jamaicans, produces an unacceptable degree of hydronephrosis in white adults (Smith, Cook \& Rhind, I972). The rate of infection and urethral complications from the indwelling urethral catheter is well known to be high (Guttmann, I953). In view of encouraging reports on the use of the fine-bore SPC (Cook \& Smith, I976) we have conducted a prospective trial, comparing IUC with SPC.

\section{Patients and Methods}

Between January and December I98I all patients aged I6 years or over,

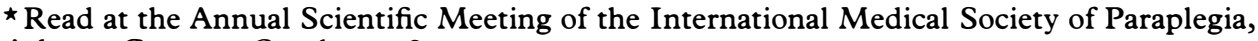
Athens, Greece. October 1982.

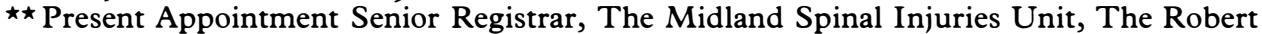
Jones and Agnes Hunt Orthopaedic Hospital, Oswestry, Shropshire SY Io 7 AG.
} 
admitted under the care of two of the authors (I.N. and J.R.S.) within $2 \mathrm{I}$ days of injury (and who would normally have been considered suitable for bladder management by IUC), were entered into the trial. Of a total of 86 patients admitted during this period 53 failed to fulfil the entry criteria (Table I). The remaining 33 patients were allocated at random to the IUC or SPC treatment groups on admission. Consent was requested from the

\section{TABLE I}

Selection of patients

Acute spinal cord injuries admitted Jan-Dec I98 I

Failure to fulfil entry criteria:

Age less than 16 years

Admitted later than $2 \mathrm{I}$ days from injury

Normal or near-normal micturition on admission

SPC in situ on admission

Too ill to enter trial

For long-term Foley catheter because of age

Entry into trial

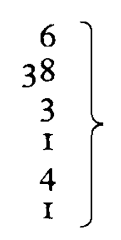

Subsequent withdrawal from trial:

Refused SPC

Condition deteriorated shortly after entry into

trial

Died 12 days after injury (pulmonary embolism)

For intermittent self-catheterisation

For long-term Foley catheter

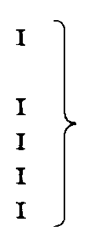

Patients completing trial

patients in the SPC group. Five were subsequently withdrawn (Table I), leaving 28 patients ( 14 in each group), who completed the trial. All patients were admitted with an indwelling Foley catheter in situ. The two groups were comparable as regards sex distribution, age, delay before admission (Table II) and neurological level of lesion. The patients were anticoagulated with warfarin or phenindione, sometimes preceded by subcutaneous heparin.

TABLE II

Sex and age distribution and delay in admission

\begin{tabular}{llll}
\hline & & IUC & SPC \\
\hline Number of patients & & I4 & I4 \\
Male/Female & & I0/4 & $9 / 5$ \\
Age in years: & range & I6-56 & I6-57 \\
& mean & 30 & 26 \\
Time in days & range & I-I9 & I-I 4 \\
from injury to & mean & 6 & 5 \\
admission to & & & \\
NSIC: & & & \\
\hline
\end{tabular}




\section{IUC Group}

The initial Foley catheter was in situ for periods ranging from 13 to 65 days, with a mean of 30 days. The patient was then either intermittently catheterised, initially three times a day and on a restricted fluid intake of I $500 \mathrm{ml}$ in 24 hours, or a Foley catheter was left in situ overnight, being removed for increasing lengths of time during the day until micturition was established. This regime differed significantly from intermittent catheterisation as described by Guttmann and Frankel (I966).

\section{SPC Group}

A Foley catheter was initially in situ for periods ranging from I-I 6 days, with a mean of 7 days. The SPC was inserted within 4 days of admission to the NSIC, with a mean delay of I day. The bladder was filled with $400-500 \mathrm{ml}$ of 0.02 per cent chlorhexidine and a fine-bore suprapubic catheter inserted according to the manufacturer's instructions (Braun, 'Cystofix') and drained continuously into a closed drainage system. The patient was instructed to drink at least 3 litres every 24 hours. After a variable time, usually at the end of the period of spinal shock, when the bulbo-cavernosus reflex re-appeared, the SPC was clamped for increasing intervals until micturition occurred. Two patients had a second SPC inserted after the first one blocked. In five patients the SPC either blocked or fell out and management was changed to IUC.

\section{Results}

The following aspects were studied.

Establishment of micturition. The period elapsing before the first spontaneous or assisted micturition was not significantly different in the two groups. The time from injury to established micturition i.e. the total length of bladder training (with the assistance of external urethral sphincterotomy if necessary), was longer in the IUC group, due mainly to two patients whose micturition was unduly delayed (Table III). Two patients in each group required sphincterotomy before micturition was established.

TABLE III

Establishment of micturition

\begin{tabular}{|c|c|c|c|}
\hline & & IUC & SPC \\
\hline $\begin{array}{l}\text { Time from injury } \\
\text { to first micturition } \\
\text { (days): }\end{array}$ & $\begin{array}{l}\text { range } \\
\text { mean }\end{array}$ & $\begin{array}{c}\text { I I }-67 \\
32\end{array}$ & $\begin{array}{c}2 \mathrm{I}-54 \\
33\end{array}$ \\
\hline $\begin{array}{l}\text { Time from injury } \\
\text { to established } \\
\text { micturition (days): }\end{array}$ & $\begin{array}{l}\text { range } \\
\text { mean }\end{array}$ & $\begin{array}{c}25-282 \\
92\end{array}$ & $\begin{array}{c}28-154 \\
58\end{array}$ \\
\hline
\end{tabular}

Urinary tract infection. There was no significant difference between the two groups in the length of time the urine remained sterile after injury (or 
in the number with infected urine), both when micturition was established and after a 3 month interval (Table IV). The first infecting organisms are shown in Table V; differences in the groups were not significant. The timing of acute febrile episodes, presumed to be due to urinary tract infection (Table VI) were similar, four episodes occurring during the actual period of IUC and three while the SPC was in situ. When expressed as acute febrile episodes per 100 days of each type of bladder management there was no significant difference between the two groups, the IUC group had 0.70 and the SPC group 0.60 acute febrile episodes per I00 patient days respectively.

Complications of instrumentation. One patient on IUC unfortunately de-

TABLE IV

Urinary tract infections ( $>\mathrm{IO}^{5}$ organisms per $\mathrm{ml}$ urine)

\begin{tabular}{lccc}
\hline & & IUC & SPC \\
\hline Number infected on admission to NSIC & 6 & 4 \\
Time to first infection (days): & range & IO-3 I & $4-37$ \\
& mean & I 4 & I6 \\
Number infected when micturition established & 8 & I3 \\
Number infected 3 months later & 6 & 2 \\
\hline
\end{tabular}

TABLE V

First infection organism

\begin{tabular}{lcc}
\hline & IUC & SPC \\
\hline E. coli & 2 & 2 \\
Proteus & 4 & - \\
Klebsiella & I & 2 \\
Strep. faecalis & I & I \\
Micrococcus & 2 & 4 \\
Staph. aureus & 2 & I \\
Acinetobacter & - & 2 \\
Mixed & 2 & 2 \\
\hline
\end{tabular}

TABLE V̄I

Time of acute febrile episodes

\begin{tabular}{|c|c|c|c|}
\hline IUC group & & SPC group & \\
\hline Before IUC instituted & $\mathbf{I}$ & Before SPC instituted & 一 \\
\hline During IUC period & 4 & During SPC period & 3 \\
\hline $\begin{array}{l}\text { During } 3 \text { month period after } \\
\text { micturition established }\end{array}$ & 2 & $\begin{array}{l}\text { Following removal of SPC } \\
\text { to end of } 3 \text { month period } \\
\text { after micturition established }\end{array}$ & 3 \\
\hline Total & 7 & & 6 \\
\hline
\end{tabular}


veloped a false passage, which almost certainly had followed difficult instrumentation. There were no failed IUCs or SPC insertions.

Haematuria. Three patients in the IUC group developed mild haematuria, two before IUC was instituted and a third during IUC. In the SPC group, in spite of easy SPC insertion in every instance, haematuria followed in three patients. This was mild in two and cleared spontaneously but a third patient required bladder washouts for clot retention.

Bladder calculi. Phosphatic debris was washed out of the bladder at cystoscopy in three patients in each group. In the IUC group a further patient required litholapaxy.

Autonomic dysreflexia. Two patients in each group developed autonomic dysreflexia, in the IUC group due to bladder distension between catheterisations and in the SPC group due to blocked catheters.

Acceptance by patients and staff. Suprapubic catheters were well accepted by both patients and staff. This was particularly true of younger female patients who found repeated urethral catheterisation distasteful. Patients welcomed the unrestricted fluid regime of SPC.

Cost of treatment. The basic cost of IUC (at the rate of three catheters

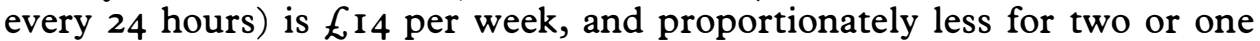
catheter every 24 hours. The basic cost of SPC is $£$ I 5 for the first week, including the cost of the catheter and its insertion and $£ 4.20$ for subsequent weeks. In this trial the average weekly cost of IUC was $£$ IO 40 , and of SPC $£ 7 \cdot 70$. In addition, average antibiotic cost in the IUC group was $£ 7.00$ and in the SPC group $£ 4.30$ per week. Labour costs were not analysed but it was generally agreed by ward staff that IUC was very timeconsuming, compared to SPC.

\section{Discussion}

This trial introduced fine-bore suprapubic catheterisation to a unit which had practised intermittent urethral catheterisation for many years. Because of familiarity with urethral catheterisation there was a natural tendency to revert to IUC when the SPC blocked, rather than insert a new SPC.

The trial showed no important clinical difference between the two methods of bladder management. Slade (I980), in discussing the general advantages of the SPC over urethral catheterisation, suggested that by its use bladder bacteriuria may be delayed for several days but this was not our experience. The main disadvantage of the SPC is its propensity to block. Long-term SPC drainage may carry a risk of developing squamouscell carcinoma in the track of the catheter but there is no evidence that short-term use carries this risk.

In all countries economic consideration of medical care are important. Fine-bore suprapubic catheterisation is a cheaper method of bladder training than intermittent urethral catheterisation, both in the cost of materials and labour. We have shown that it is an acceptable alternative to intermittent urethral catheterisation and is the method of choice in the young female 
patient. We believe that its use in the acute stage following spinal cord injury should become more widespread.

\section{RÉSUMÉ}

Une épreuve en perspective a été conduite pour comparer l'emploi du cathètre suprapubique à petit diamètre et du cathètre intermittant comme méthode de drainer la vessie pendant la phase qui suit à un endommagement de la moelle épinaire. Les résultats n'ont montré aucune différence importante entre les deux méthodes de traitement de la vessie. L'emploi du cathètre supra-pubique à petit diamètre convient en particulier aux jeunes patientes pour qui l'emploi répété du cathètre est désagréable; pour d'autres patients il fournit une alternative à l'emploi d'un cathètre intermittant, surtout si les considérations économiques l'emportent.

\section{ZUSAMMENFASSUNG}

Eine vorwärtsschauende Probe wurde angestellt, die die Anwendung eines suprapubischen Katheters mit kleinem Durchmesser und eines intermittierenden Katheters als Methoden um die Blase zu entleeren im akuten Stadium, das nach einer Beschädigung des Rückenmarks eintritt, verglich. Die Ergebuisse haben keinen wichtigen Untershied zwischen den zwei Methoden von Blasenbehandlung bewiesen. Die Anwendung eines suprapubischen Katheters mit kleinem Durchmesser ist für junge Patientinnen, für die die wiederholte Anwendung eines Katheters widerlich ist, besonders gut geeignet; für andre Patienten ist sie eine gut akzeptierte Alternative zur Anwendung eines intermittierenden Katheters, besonders wo ökonomische Umstände überwiegend sind.

\section{REFERENCES}

Cook, J. B. \& SMITh, P. H. (1976). Percutaneous suprapubic cystostomy after spinal cord injury. Brit. F. Urol., 48, I I9-I 2 I.

GolDING, J. S. R. (I968). Early management of traumatic paraplegia in males. Rehabilitation, 66, 49.

GutTMANN, L. (1947). Discussion on treatment and prognosis of traumatic paraplegia. Proc. Roy. Soc. Med., 40, 219-232.

Guttmann, L. (1953). Medical history of the Second World War. Monograph. Vol. Surg. H.M. Stationery Office, London.

Guttmann, L. \& Frankel, H. (1966). The value of intermittent catheterisation in the early management of traumatic paraplegia and tetraplegia. Paraplegia, 4, 63-84.

SLADE, N. (I980). Postoperative urinary tract infection in urology and gynaecology: a review. F. Roy. Soc. Med., 73, 739-743.

Smith, P. H., Cook, J. B. \& RHIND, J. R. (1972). Manual expression of the bladder following spinal injury. Paraplegia, 9, 2 13-218.

SMith, P. H., Cook, J. B. \& Robertson, W. G. (I969). Stone formation in paraplegia. Paraplegia, 7, 77-85. 